\title{
Ideology, Equality, and the New Right
}

\author{
Michael W. Apple \\ University of Wisconsin
}

\section{Introduction}

We live in a period in which our educational system has become increasingly politicized. The curriculum and the values that underpin it and that are included and excluded from it are now being placed under intense ideological scrutiny. The Spencerian question, "What knowledge is of most worth?" has now been replaced with an even more pointed question, "Whose knowledge is of most worth?" That this latter question has become so powerful highlights the profoundly political nature of educational policy and practice. This is not simply an abstract issue. It is made strikingly clear in the fact that the curriculum of many school districts throughout the country has been turned into what can best be described as a political football. Conservative groups in particular have attacked the school and, in the process, have had a major impact on educational debate, not only in the United States, but in other nations as well.

As is evident all around us, there has been a significant shift in public discourse around education. The rapid growth of evangelical schooling (Rose, 1988), the court cases involving "secular humanist" tendencies in textbooks, the increasing attempts to raise the standards of teaching and teachers, and the calls in the literature to return to a core curriculum of a common culture all signify a deep suspicion among many social groups of what is going on in our classrooms. There are very real fears - usually among right-wing groups, but also to be found in official statements coming out of the federal and state governments-that for the past decade things have gotten out of control. In this vision, we are losing control both of our children and of the pace of social and cultural change. We have gone too far in tilting our educational and social policies toward minority groups and women. This is not equality, but reverse discrimination. It goes beyond the bounds of what is acceptable. Not only is the search for a more egalitarian set of policies misplaced, but it fails the test of cost/benefit analysis. It is simply too expensive in practice to work and, as well, gives things to people that they have not really earned. 
The position is especially evident in quotes from former Secretary of Education William Bennett. In his view, we are finally emerging from a crisis in which "we neglected and denied much of the best in American education. For a period, we simply stopped doing the right things [and] allowed an assault on intellectual and moral standards." This assault on the current state of education, which, as I noted above, the conservatives see as being connected with attacks on the family, traditional values, religiosity, patriotism, and our economic well being, has led schools to fall away from "the principles of our tradition" (Bennett, 1988).

Yet, for Bennett, "the people" have now risen up. "The 1980s gave birth to a grass-roots movement for educational reform that has generated a renewed commitment to excellence, character, and fundamentals. Because of this, "we have reason for optimism" (Bennett, 1980). Why? Because

The national debate on education is now focused on truly important matters: mastering the basics ... insisting on high standards and expectations; ensuring discipline in the classroom; conveying a grasp of our moral and political principles; and nurturing the character of our young. (p. 10)

In essence, our educational system has become too committed to a problematic vision of equality. In the process, "our" standards, the cultural and intellectual values of the western tradition, our very greatness as a nation-and the moral fiber on which it rests - are at risk. Just as much at risk is our economic stability and our ability to compete internationally in the global market. All these points are part of a contradictory bundle of assertions. Yet all are having real effects on education and on the language and conceptual apparatus we employ to think about its role in society.

Concepts do not remain still very long. They have wings, so to speak, and can be induced to fly from place to place. It is this context that defines their meaning. As Wittgenstein so nicely reminded us, one should look for the meaning of language in its specific contextual use. This is especially important in understanding political and educational concepts, because they are part of a larger social context, a context that is constantly shifting and is subject to severe ideological conflicts. Education itself is an arena in which these ideological conflicts work themselves out. It is one of the major sites where different groups with distinct political, economic, and cultural visions attempt to define what the socially legitimate means and ends of a society are to be. 
In this article, I want to situate the concern with equality in education within these larger conflicts. I place its shifting meanings both within the breakdown of the largely liberal consensus that guided much educational and social policy since World War II, and within the growth of the new right and conservative movements over the past two decades that have had a good deal of success in redefining what education is for and in shifting the ideological texture of the society profoundly to the right (Apple, 1986a; Giroux, 1984). In the process, I document how new social movements gain the ability to redefine-often, though not always, in retrogressive ways-the terms of debate in education, social welfare, and other areas of the common good. At root, my claim is that it is impossible to fully comprehend the value conflicts underlying so much of the debate in education and the shifting fortunes of the assemblage of concepts surrounding equality (equality of opportunity, equity, etc.) unless we have a much clearer picture of society's already unequal cultural, economic, and political dynamics that provide the center of gravity around which education functions.

\section{Between Property Rights and Person Rights}

As I have argued at greater length elsewhere, what we are witnessing today is nothing less than the recurrent conflict between property rights and person rights that has been a central tension in our economy (Apple, 1985, 1986a). Gintis (1980) defines the differences between property rights and person rights in the following way.

A property right vests in individuals the power to enter into social relationships on the basis and extent of their property. This may include economic rights of unrestricted use, free contract, and voluntary exchange; political rights of participation and influence; and cultural rights of access to the social means for the transmission of knowledge and the reproduction and transformation of consciousness. A person right vests in individuals the power to enter into these social relationships on the basis of simple membership in the social collectivity. Thus, person rights involve equal treatment of citizens, freedom of expression and movement, equal access to participation in decision-making in social institutions, and reciprocity in relations of power and authority. (p. 193)

The attempts to enhance person rights partly rest on a notion of what is best thought of as positive liberty, freedom to as well as freedom from. In industrial nations, this has grown stronger over the years as many previously disenfranchised groups of women and men demanded suffrage. The right to equal political participation would be based on being a person rather than on 
ownership of property (or, later on, being a white male). Further, person rights have been extended to include the right of paid workers to form unions, to organize a common front against their employers. At the same time, claims about the right to have a job with dignity and decent pay have been advanced. And, finally, there have been demands that economic transactions-from equal treatment of women and racial minorities in employment, pay, and benefits to health and safety for everyone-are to be governed by rules of due process and fairness, thereby restricting management powers of unrestricted use and "free contract" (Gintis, 1980, p. 196).

This last point is important because it documents a growing tendency to take ideas of civil equality and apply them to the economic sphere. Thus "the right to equal treatment in economic relationships, which directly expresses the dominance of person over property rights, has been an explicit demand of women, racial minorities, immigrant workers, and others" (Gintis, 1980, p. 197). This too has been accompanied by further gains in which the positive rights of suffrage and association that have been won by women and by minority and working class groups have been extended to include what increasingly became seen as a set of minimum rights due any individual simply by the fact of citizenship. These included state supported services in the areas of health, education, and social security; consumer protection laws; lifeline utility guarantees; and occupational safety and health regulations. In their most progressive moments, these tendencies led to arguments for full workplace democracy, democratic control over investment decisions, and the extension of the norms of reciprocity and mutual participation and control in most areas of social life from the paid workplace and the political life of local communities and schools to the home (p. 197). Taken together these movements did constitute at least a partial restructuring of the balance between person rights and property rights, one that would soon be challenged by powerful groups.

It is not surprising that in our society dominant groups "have fairly consistently defended the prerogatives of property," while subordinate groups on the whole have sought to advance "the prerogatives of persons" (Gintis, 1980, p. 194; see also Bowles \& Gintis, 1986). In times of severe upheaval, these conflicts become even more intense, and, given the current balance of power in society, advocates of property rights have once again been able to advance their claims for the restoration and expansion of their prerogatives, not only in education, but in all our social institutions. 
The United States economy is in the midst of one of the most powerful structural crises it has experienced since the depression. In order to solve it on terms acceptable to dominant interests, as many aspects of the society as possible need to be pressured into conforming with the requirements of international competition, reindustrialization, and (in the words of the National Commission on Excellence in Education, 1983) "rearmament" (pp. 12-16). The gains made by women and men in employment, health and safety, welfare programs, affirmative action, legal rights, and education must be rescinded because "they are too expensive" both economically and ideologically.

Both of these latter words are important. Not only are fiscal resources scarce (in part because current policies transfer them to the military), but people must be convinced that their belief that person rights come first is simply wrong or outmoded given current realities. Thus intense pressure must be brought to bear through legislation, persuasion, administrative rules, and ideological maneuvering to create the conditions right-wing groups believe are necessary to meet these requirements (Apple, 1986a).

In the process, not just in the United States, but in Britain and Australia as well, the emphasis of public policy has materially changed from issues of employing the state to overcome disadvantage. Equality, no matter how limited or broadly conceived, has become redefined. No longer is it seen as linked to past group oppression and disadvantagement. It is simply now a case of guaranteeing individual choice under the conditions of a "free market" (Anderson, 1985, pp. 6-8). Thus the current emphasis on "excellence" (a word with multiple meanings and social uses) has shifted educational discourse so that underachievement is once again increasingly seen as largely the fault of the student. Student failure, which was at least partly interpreted as the fault of severely deficient educational policies and practices, is now being seen as the result of what might be called the biological and economic marketplace. This is evidenced in the growth of forms of Social Darwinist thinking in education and in public policy in general (Bastian, Fruchter, Gittell, Greer, $\&$ Haskins, 1986, p. 14). In a similar way, behind a good deal of the rhetorical artifice of concern about the achievement levels in, say, inner city schools, notions of choice have begun to evolve where deep-seated school problems will be solved by establishing free competition over students. These assume that by expanding the capitalist marketplace to schools we will somehow compensate for the decades of economic and educational neglect experienced by the communities in which these schools are 
found. ${ }^{1}$ Finally, there are concerted attacks on teachers (and curricula) based on a profound mistrust of their quality and commitments.

All this has led to an array of educational conflicts that have been instrumental in shifting the debates over education profoundly to the right. The effects of this shift can be seen in a number of educational policies and proposals now gaining momentum throughout the country: (a) proposals for voucher plans and tax credits to make schools more like the idealized free-market economy; (b) the movement in state legislatures and state departments of education to "raise standards" and mandate both teacher and student "competencies" and basic curricular goals and knowledge, thereby centralizing even more at a state level the control of teaching and curricula; (c) the increasingly effective assaults on the school curriculum for its supposedly antifamily and antifree-enterprise bias, its secular humanism, its lack of patriotism, and its neglect of the western tradition; and (d) the growing pressure to make the needs of business and industry into the primary goals of the educational system (Apple, 1986b, pp. 171-190). These are major alterations that have taken years to show their effects. Though I paint in rather broad strokes here, an outline of the social and ideological dynamics of how this has occurred should be visible.

\section{The Restoration Politics of Authoritarian Populism}

The first thing to ask about an ideology is not what is false about it, but what is true. What are its connections to lived experience? Ideologies properly conceived do not dupe people. To be effective they must connect to real problems, real experiences (Apple, 1990; Larrain, 1983). As I document, the movement away from social democratic principles and an acceptance of more right-wing positions in social and educational policy occur precisely because conservative groups have been able to work on popular sentiments; to reorganize genuine feelings; and, in the process, to win adherents.

Important ideological shifts are not caused only by powerful groups "substituting one, whole, new conception of the world for another." Often, these shifts occur through the presentation of novel combinations of old and new elements (Hall, 1985, p. 122). Let us take the positions of the Reagan administration, which will, by and large, provide the framework for the Bush administration's policies as well, as a case in point, for as Clark and Astuto (1986) have demonstrated in education and Piven and Cloward (1982) and Raskin (1986) have shown in the larger areas of social policy, significant and enduring alterations have 
occurred in the ways policies are carried out and in the content of those policies. ${ }^{2}$

The success of the policies of the Reagan administration, like that of Thatcherism in Britain, should not be evaluated simply in electoral terms. The policies need to be judged by their success as well in disorganizing other more progressive groups; in shifting the terms of political, economic, and cultural debate onto the terrain favored by capital and the right (Hall \& Jacques, 1983, p. 13) In these terms, there can be no doubt that the current right-wing resurgence has accomplished no small amount in its attempt to construct the conditions that will put it in a hegemonic position.

The right in the United States and Britain has thoroughly renovated and reformed itself. It has developed strategies based on what might best be called an authoritarian populism (Hall, 1980, pp. 160-161). As defined by Hall, such a policy is based on an increasingly close relationship between government and the capitalist economy, a radical decline in the institutions and power of political democracy, and attempts at curtailing "liberties" that have been gained in the past. This is coupled with attempts to build a consensus, which is widespread, in support of these actions (Hall, 1980, p. 161). The new right's authoritarian populism (Hall, 1985; Jessop, Bennett, Bromley, \& Ling, $1984)^{3}$ has exceptionally long roots in the history of the United States. The political culture here has always been influenced by the values of the dissenting Protestanism of the 17th century. Such roots become even more evident in periods of intense social change and crisis (Omi \& Winant, 1986, p. 214). As Burnham (1983) has put it:

Whenever and wherever the pressures of "modernization"secularity, urbanization, the growing importance of sciencehave become unusually intense, episodes of revivalism and culture-issue politics have swept over the social landscape. In all such cases since at least the end of the Civil War, such movements have been more or less explicitly reactionary, and have frequently been linked with other kinds of reaction in explicitly political ways. (p. 125)

The new right works on these roots in creative ways, modernizing them and creating a new synthesis of their varied elements by linking them to current fears. In so doing, the right has been able to rearticulate traditional political and cultural themes and because of this has effectively mobilized a large amount of mass support. 
As I noted, part of the strategy has been the attempted dismantling of the welfare state and of the benefits that working people, racial minorities, and women (these categories are obviously not mutually exclusive) have won over decades of hard work. This has been done under the guise of antistatism, of keeping government "off the backs of the people," and of "free enterprise." Yet, at the same time, in many valuative, political, and economic areas the current government is extremely statecentrist both in its outlook, and, very importantly, in its day-today operations (Hall, 1985, p. 117).

One of the major aims of a rightist restoration politics is to struggle in many different arenas at the same time, not only in the economic sphere, but in education and elsewhere as well. This aim is grounded in the realization that economic dominance must be coupled to "political, moral, and intellectual leadership" if a group is to be truly dominant and if it genuinely wants to restructure a social formation. Thus, as both Reaganism and Thatcherism recognized so clearly, to win in the state you must also win in civil society (Hall, 1985, p. 112). As the noted Italian political theorist Gramsci would put it, what we are seeing is a war of position. "It takes place where the whole relation of the state to civil society, to 'the people' and to popular struggles, to the individual and to the economic life of society is thoroughly reorganized, where 'all the elements change"' (Hall, 1980, p. 166).

In this restructuring, Reaganism and Thatcherism did not create some sort of false consciousness, creating ways of seeing that had little connection with reality. Rather, they "operated directly on the real and manifestly contradictory experiences" of a large portion of the population. They did connect with the perceived needs, fears, and hopes of groups of people who felt threatened by the range of problems associated with the crises in authority relations, in the economy, and in politics (Hall, 1983).

What has been accomplished is a successful translation of an economic doctrine into the language of experience, moral imperative, and common sense. The free-market ethic has been combined with a populist politics. This has meant the blending of a rich mix of themes that have had a long history-nation, family, duty, authority, standards, and traditionalism-with other thematic elements that have also struck a resonant chord during a time of crisis. These latter themes include self-interest, competitive individualism (what I have elsewhere called the possessive individual, Apple, 1985), and antistatism. In this 
way, a reactionary common sense is partly created (Hall, 1983, pp. 29-30).

The sphere of education has been one of the most successful areas where the right has been ascendant. The social democratic goal of expanding equality of opportunity (itself a rather limited reform) has lost much of its political potency and ability to mobilize people. The panic over falling standards and illiteracy, the fears of violence in schools, the concern with the destruction of family values and religiosity all have had an effect. These fears are exacerbated, and used, by dominant groups in politics and the economy who have been able to move the debate on education (and all things social) onto their own terrain, that of traditionalism, standardization, productivity, and industrial needs (Hall, 1983, pp. 36-37; Hunter, 1984). Because so many parents are justifiably concerned about the economic futures of their children-in an economy that is increasingly conditioned by lowered wages, unemployment, capital flight, and insecurity (Apple, 1986a)-rightist discourse connects with the experiences of many working-class and lower-middle-class people.

However, while this conservative conceptual and ideological apparatus does appear to be rapidly gaining ground, one of the most critical issues remains to be answered. How is such an ideological vision legitimated and accepted? How was this done (Jessop, Bennett, Bromley, \& Ling, 1984, p. 49)?

\section{Understanding the Crisis}

The right-wing resurgence is not simply a reflection of the current crisis. Rather, it is itself a response to that crisis (Hall, 1983 , p. 21). Beginning in the immediate post World War II years, the political culture of the United States was increasingly characterized by American imperial might, economic affluence, and cultural optimism. This period lasted for more than two decades. Socially and politically it was a time of what has been called the social democratic accord, when government increasingly became an arena for a focus on the conditions required for equality of opportunity. Commodity driven prosperity, the extension of rights and liberties to new groups, and the expansion of welfare provisions provided the conditions for this compromise both between capital and labor and with historically more dispossessed groups such as blacks and women. This accord has become mired in crisis since the late 1960s and early 1970s (Hunter, 1987, pp. 1-3).

Hunter (1987) gives an excellent sense of this in his own description of this accord. 
From the end of World War II until the early 1970 s world capitalism experienced the longest period of sustained economic growth in its history. In the United States a new "social structure of accumulation"-the specific institutional environment within which the capitalist accumulation process is organized-was articulated around several prominent features: the broadly shared goal of sustained economic growth, Keynesianism, elite pluralist democracy, an imperial America prosecuting a cold war, anticommunism at home and abroad, stability or incremental change in race relations and a stable home life in a buoyant, commoditydriven consumer culture. Together these crystallized a basic consensus and a set of social and political institutions which was hegemonic for two decades. (p. 9)

At the very center of this hegemonic accord was a compromise reached between capital and labor in which labor accepted what might be called "the logic of profitability and markets as the guiding principles of resource allocation." In return they received "an assurance that minimal living standards, trade union rights and liberal democratic rights would be protected" (Bowles, 1982, p. 51). These democratic rights were further extended to the poor, women, and racial minorities as these groups expanded their own struggles to overcome racially and sexually discriminatory practices (Hunter, 1987, p. 12). Yet this extension of (limited) rights could not last, given the economic and ideological crises that soon beset American society: a set of crises that challenged the very core of the social democratic accord.

The dislocations of the 1960s and 1970s - the struggle for racial and sexual equality, military adventures such as Vietnam, Watergate, the resilience of the economic crisis-produced both shock and fear. Mainstream culture was shaken to its very roots in many ways. Widely shared notions of family, community, and nation were dramatically altered. Just as importantly, no new principle of cohesion emerged that was sufficiently compelling to recreate a cultural center. As economic, political, and valuative stability (and military supremacy) seemed to disappear, the polity was itself balkanized. Social movements based on difference-regional, racial, sexual, religious-became more visible (Omi \& Winant, 1986, pp. 214-215). The sense of what Raskin (1986) has called "the common good" was fractured.

Traditional social democratic "statist" solutions which in education, welfare, health, and other similar areas took the form of large scale attempts at federal intervention to increase opportunities or to provide a minimal level of support were seen as 
being part of the problem, not as part of the solution. Traditional conservative positions were more easily dismissed as well. After all, the society on which they were based was clearly being altered. The cultural center could be built (and it had to be built by well-funded and well-organized political and cultural action) around the principles of the new right. The new right confronts the "moral, existential, [and economic] chaos of the preceding decades" with a network of exceedingly well-organized and financially secure organizations incorporating "an aggressive political style, on outspoken religious and cultural traditionalism and a clear populist commitment" (Hunter, 1984; Omi \& Winant, 1986, pp. 215-216).

In different words, the project was aimed at constructing a new majority that would "dismantle the welfare state, legislate a return to traditional morality, and stem the tide of political and cultural dislocation which the 1960 s and 1970 s represented." Using a populist political strategy (now in combination with an aggressive executive branch of the government), it marshalled an assault on "liberalism and secular humanism" and linked that assault to what some observers have argued was "an obsession with individual guilt and responsibility where social questions are concerned (crime, sex, education, poverty)" with strong beliefs against government intervention (Omi \& Winant, 1986, p. 220; for a more complete discussion of how this has affected educational policy in particular, see Apple, 1986a; Clark \& Astuto, 1986).

The class, racial, and sexual specificities here are significant. The movement to create a conservative cultural consensus in part builds on the hostilities of the working and lower middle classes toward those above and below them and is fueled by a real sense of antagonism against the new middle class. State bureaucrats and administrators, educators, journalists, planners, and so on all share part of the blame for the social dislocations these groups have experienced (Apple, 1986a; Omi \& Winant, 1986 , p. 221). ${ }^{5}$ Race, sex, and class themes abound here, a point to which I return in the next section of my analysis.

This movement is, of course, enhanced in academic and government circles by a group of policy-oriented neoconservatives who have become the organic intellectuals for much of the rightist resurgence. A society based on individualism, market-based opportunities, and the drastic reduction of both state intervention and state support are all currents that run deep in their work (Omi \& Winant, 1986, p. 227). They provide a counterpart to the new right and are themselves part of the inherently unstable alliance that has been formed. 


\section{Building the New Accord}

Almost all the reform minded social movements-including the feminist, gay and lesbian, student, and other movements of the 1960 s - drew on the struggle by blacks "as a central organizational fact or as a defining political metaphor and inspiration" (Omi \& Winant, 1986, p. 164). These social movements infused new social meanings into politics, economics, and culture. These are not separate spheres. All three of these levels exist simultaneously. New social meanings about the importance of person rights infused individual identity, family, and community and penetrated state institutions and market relationships. These emerging social movements expanded the concerns of politics to all aspects of the terrain of everyday life. Person rights took on ever more importance in nearly all of our institutions, as evidenced in aggressive affirmative action programs, widespread welfare and educational activist programs, and so on (Omi \& Winant, 1986; see also Bowles \& Gintis, 1986). ${ }^{6}$ In education this was very clear in the growth of bilingual programs and in the development of women's, black, Hispanic, and Native American studies in high schools and colleges.

For a number of reasons the state was the chief target of these earlier social movements for gaining person rights. First, the state was the "factor of cohesion in society" and had historically maintained and organized practices and policies that embodied the tension between property rights and person rights (Apple, $1985 ; 1986 a)$. It was natural to focus on such a factor of cohesion. Second, "the state was traversed by the same antagonisms which penetrated the larger society, antagonisms that were themselves the resulis of past cycles of [social] struggle." Openings in the state could be gained because of this. Footholds in state institutions dealing with education and social services could be deepened (Omi \& Winant, 1986, pp. 177-178).

Yet even with these gains the earlier coalitions began to disintegrate. In the minority communities class polarization deepened. The majority of barrio and ghetto residents "remained locked in poverty," while a relatively small portion of the black and Hispanic population were able to take advantage of educational opportunities and new jobs (the latter being largely within the state itself, Omi \& Winant, 1986, pp. 177-178). With the emerging crisis in the economy, something of a zero-sum game developed in which progressive social movements had to fight over a limited share of resources and power. Antagonistic rather than complementary relationships developed among groups. Minority groups, for example, and the largely white and middle- 
class women's movement had difficulty integrating their programs, goals, and strategies.

This was exacerbated by the fact that, unfortunately, given the construction of a zero-sum game by dominant groups, the gains made by women sometimes came at the expense of blacks and Hispanics. Furthermore, leaders of many of these movements had been absorbed into state sponsored programs which-while the adoption of such programs was in part a victory-had the latent affect of cutting off leaders from their grass-roots constituency and lessened the militancy at this level. This often resulted in what has been called the ghettoization of movements within state institutions as movement demands were partly adopted in their most moderate forms into programs sponsored by the state. Militancy is transformed into constituency (Omi \& Winant, 1986, p. 180).

The splits in these movements occurred as well because of strategic divisions, divisions that were paradoxically the results of the movements' own successes. Thus, for example, those women who aimed their work within existing political/economic channels could point to gains in employment within the state and in the economic sphere. Other, more radical, members saw such "progress" as "too little, too late" (Omi \& Winant, 1986).

Nowhere is this more apparent than in the African American movement in the United States. It is worth quoting one of the best analyses of the history of these divisions at length.

The movement's limits also arose from the strategic divisions that befell it as a result of its own successes. Here the black movement's fate is illustrative. Only in the South, while fighting against a backward political structure and overt cultural oppression, had the black movement been able to maintain a decentered unity, even when internal debates were fierce. Once it moved north, the black movement began to split, because competing political projects, linked to different segments of the community, sought either integration in the (reformed) mainstream, or more radical transformation of the dominant racial order.

After initial victories against segregation were won, one sector of the movement was thus reconstituted as an interest-group, seeking an end to racism understood as discrimination and prejudice, and turning its back on the oppositional "politics of identity." Once the organized black movement became a mere constituency, though, it found itself locked in a bear hug with the state institutions whose programs it had itself demanded, while simultaneously isolated from the core institutions of the modern state. (Omi \& Winant, 1986, p. 190) 
In the process, those sectors of the movement that were the most radical were marginalized or, and this must not be forgotten, were simply repressed by the state (Omi \& Winant, 1986, p. 190).

Although there were major gains, the movements' integration in to the state latently created conditions that were disastrous in the fight for equality. A mass-based militant grass-roots movement was defused into a constituency dependent on the state itself. And, very importantly, when the neoconservative and right-wing movements evolved with their decidedly antistatist themes, the gains that were made in the state come increasingly under attack and the ability to recreate a large-scale grass-roots movement to defend these gains was weakened considerably (Omi \& Winant, 1986). Thus, when there are right-wing attacks on the more progressive national and local educational policies and practices that have benefited racial minorities, it becomes increasingly difficult to develop broad-based coalitions to counter these offensives.

In their failure to consolidate a new "radical" democratic politics, with majoritarian aspirations, the new social movements of the 1960s and 1970s "provided the political space in which right wing reaction could incubate and develop its political agenda" (Omi \& Winant, 1986, p. 252). Thus state reforms won by, say, minority movements in the 1960s in the United States and the new definitions of person rights embodied in these reforms "provided a formidable range of targets for the "counter-reformers' of the 1970s." Neoconservatives and the new right carried on their own political "project." They were able to rearticulate particular ideological themes and to restructure them around a political movement once again (p. 155). And these themes were linked to the dreams, hopes, and fears of many individuals.

Let us examine this in more detail. Behind the conservative restoration is a clear sense of loss: of control, of economic and personal security, of the knowledge and values that should be passed on to children, of visions of what counts as sacred texts and authority. The binary opposition of we/they becomes very important here. "We" are law abiding, "hard working, decent, virtuous, and homogeneous." The "theys" are very different. They are "lazy, immoral, permissive, heterogeneous" (Hunter, 1987 , p. 23). These binary oppositions distance most racial minorities, women, gays, and others from the community of worthy individuals. The subjects of discrimination are now no longer those groups who have been historically oppressed, but are instead the "real Americans" who embody the idealized virtues of a romanticized past. The "theys" are undeserving. 
They are getting something for nothing. Policies supporting them are "sapping our way of life," most of our economic resources, and creating government control of our lives (p. 30).

These processes of ideological distancing make it possible for antiblack and antifeminist sentiments to seem no longer racist and sexist because they link so closely with other issues. Once again, Hunter (1987) is helpful.

Racial rhetoric links with anti-welfare state sentiments, fits with the push for economic individualism; thus many voters who say they are not prejudiced (and may not be by some accounts) oppose welfare spending as unjust. Anti-feminist rhetoric ... is articulated around defense of the family, traditional morality, and religious fundamentalism. (p. 33)

All these elements can be integrated through the formation of ideological coalitions that enable many Americans who themselves feel under threat to turn against groups of people who are even less powerful than themselves. At the same time, it enables them to "attack domination by liberal, statist elites" (Hunter, 1987, p. 34).

This ability to identify a range of others as enemies as the source of the problems is significant. One of the major elements in this ideological formation has indeed been a belief that liberal elites within the state "were intruding themselves into home life, trying to impose their values." This was having serious negative effects on moral values and on traditional families. Much of the conservative criticism of textbooks and curricula rests on these feelings, for example. While this position certainly exaggerated the impact of the "liberal elite," and while it certainly misrecognized the power of capital and of other dominant classes, (Hunter, 1987, p. 21) there was enough of an element of truth in it for the right to use it in its attempts to dismantle the previous accord and build its own.

A new hegemonic accord is reached, then. It combines dominant economic and political elites intent on "modernizing" the economy, white working-class and middle-class groups concerned with security, the family, and traditional knowledge and values, and economic conservatives (Hunter, 1987, p. 37). It also includes a fraction of the new middle class whose own advancement depends on the expanded use of accountability, efficiency, and management procedures which are their own cultural capital (Apple, 1986a, 1986b). This coalition has partly succeeded in altering what it means to have a social goal of equality. The citizen as free consumer has replaced the previously emerging citizen as situated in structurally generated relations of 
domination. Thus the common good is now to be regulated exclusively by the laws of the market, free competition, private ownership, and profitability. In essence, the definitions of freedom and equality are no longer democratic, but commercial (Hall, 1986, pp. 35-36). This is particularly evident in the proposals for voucher plans as solutions to massive and historically rooted relations of economic and cultural inequality.

\section{Will the Right Succeed?}

So far I have broadly traced out many of the political, economic, and ideological reasons that the social democratic consensus that led to the limited extension of person rights in education, politics, and the economy slowly disintegrated. At the same time, I have documented how a new "hegemonic bloc" is being formed, coalescing around new right tactics and principles. The question remains: Will this accord be long lasting? Will it be able to inscribe its principles into the heart of the American polity?

There are real obstacles to the total consolidation in the state of the new right political agenda. First, there has been something of a great transformation in, say, racial identities. Omi and Winant (1986) describe it as follows:

The forging of new collective racial identities during the $1950 \mathrm{~s}$ and 1960s has been the enduring legacy of the racial minority movements. Today, as gains won in the past are rolled back and most organizations prove unable to rally a mass constituency in racial minority communities, the persistence of the new racial identities developed during this period stands out as the single truly formidable obstacle to the consolidation of a newly repressive racial order. (p. 165)

Thus, even when social movements and political coalitions are fractured, when their leaders are coopted, repressed, and sometimes killed, the racial subjectivity and self-awareness that were developed by these movements has taken permanent hold. "No amount of repression or cooption [can] change that" (Omi \& Winant, 1986, p. 166). In Omi and Winant's words, the genie is out of the bottle (p. 166). This is the case because, in essence, a new kind of person has been created within minority communities. ${ }^{7}$ A new, and much more self-conscious, collective identity has been forged. Thus, for instance, in the struggles over the past three decades by people of color to have more control of education and to have it respond more directly to their own culture and collective histories, these people themselves were transformed in major ways (Hogan, 1982). Thus:

Social movements create collective identity by offering their adherents a different view of themselves and their world; different, 
that is, from the world view and self-concepts offered by the established social order. They do this by the process of rearticulation, which produces new subjectivity by making use of information and knowledge already present in the subject's mind. They take elements and themes of her/his culture and traditions and infuse them with new meaning. (Omi \& Winant, 1986 , p. 166)

These meanings will make it exceedingly difficult for the right to incorporate the perspectives of racial minorities under its ideological umbrella and will continually create oppositional tendencies in the black and Hispanic communities. The slow but steady growth in the power of racial minorities at a local level in these communities will serve as a countervailing force to the solidification of the new conservative accord.

Added to this is the fact that, even in the new hegemonic bloc, even in the conservative restoration coalition, there are ideological strains that may have serious repercussions on its ability to be dominant for an extended period. These tensions are partly generated because of the class dynamics in the coalition. Fragile compromises may come apart because of the sometimes directly contradictory beliefs held by many of the partners in the new accord.

This can be seen in the example of two of the groups now involved in supporting the accord. There are both what can be called residual and emergent ideological systems or codes at work here. The residual culture and ideologies of the old middle class and of an upwardly mobile portion of the working class and lower middle class - stressing control, individual achievement, "morality," and so on-has been merged with the emergent code of a portion of the new middle class - getting ahead, technique, efficiency, bureaucratic advancement, and so on (Apple, 1986b).

These codes are in an inherently unstable relationship. The stress on new right morality does not necessarily sit well with an amoral emphasis on careerism and economic norms. The merging of these codes can only last as long as paths to mobility are not blocked. The economy must pay off in jobs and mobility for the new middle class or the coalition is threatened. There is no guarantee, given the unstable nature of the economy and the kinds of jobs being created, that this payoff will occur (Apple, 1986a; Carnoy, Shearer, \& Rurberger, 1984).

This tension can be seen in another way which shows again that, in the long run, the prospects for such a lasting ideological coalition are not necessarily good. Under the new, more conser- 
vative accord, the conditions for capital accumulation and profit must be enhanced by state activity as much as possible. Thus the free market must be set loose. As many areas of public and private life as possible need to be brought into line with such privatized market principles, including the schools, health care, welfare, housing, and so on. Yet, in order to create profit, capitalism by and large also requires that traditional values be subverted. Commodity purchasing and market relations become the norm and older values of community, "sacred knowledge," and morality will need to be cast aside. This dynamic sets in motion the seeds of possible conflicts in the future between the economic modernizers and the new right cultural traditionalists who make up a significant part of the coalition that has been built (Apple, 1986b). ${ }^{8}$ Furthermore, the competitive individualism now being so heavily promoted in educational reform movements in the United States may not respond well to traditional working-class and poor groups' somewhat more collective senses.

Finally, there are counterhegemonic movements now being built in education itself. The older social democratic accord included many educators, union leaders, minority group members, and others. There are signs that the fracturing of this coalition may be only temporary. Take teachers, for instance. Even though salaries have been on the rise throughout the country, this has been countered by a rapid increase in the external control of teachers' work, the rationalization and deskilling of their jobs, and the growing blame on teachers and education in general for most of the major social ills that beset the economy (Apple, 1985, 1986a). Many teachers have organized around these issues, in a manner reminiscent of the earlier work of the Boston Women's Teachers' Group (Freedman, Jackson, \& Boles, 1982). Furthermore, there are signs throughout the country of multiracial coalitions being built among elementary and secondary school teachers, university-based educators, and community members to act collectively on the conditions under which teachers work and to support the democratization of curriculum and teaching and a rededication to the equalization of access and outcomes in schooling. The Southern Coalition for Educational Equity and the Rethinking Schools group based in Milwaukee provide but a few of these examples (Apple, 1986a; Bastian et al., 1986; Livingstone, 1987).

Even given these emerging tensions in the conservative restoration and the increase once again of alliances to counter its attempted reconstruction of the politics and ethics of the com- 
mon good, this does not mean we should be at all sanguine. It is possible that, because of these tensions and counter movements, the right's economic program will fail. Yet its ultimate success may be in shifting the balance of class forces considerably to the right and in changing the very ways we consider the common good (Hall, 1983, p. 120). Privatization, profit, and greed may still substitute for any serious collective commitment.

We are, in fact, in danger both of forgetting the decades of hard work it took to put even a limited vision of equality on the social and educational agenda and of forgetting the reality of the oppressive conditions that exist for so many of our fellow Americans. The task of keeping alive in the minds of the people the collective memory of the struggle for equality, for person rights in all of the institutions of our society, is one of the most significant tasks educators can perform. In a time of conservative restoration, we cannot afford to ignore this task. This requires renewed attention to important curricular questions. Whose knowledge is taught? Why is it taught in this particular way to this particular group? How do we enable the histories and cultures of the majority of working people, of women, of racial minorities (these groups, again, are obviously not mutually exclusive) to be taught in responsible and responsive ways in schools? Given that the collective memory that now is preserved in our educational institutions is more heavily influenced by dominant groups in society (Apple, 1990), the continuing efforts to promote more democratic curricula and teaching are more important now than ever. This needs to be done in concert with other more political movements that wish to extend the substance of democracy in all of our institutions. Action in education is made that much more powerful, and more likely to succeed, if it is organically connected to democratic social movements in the larger society (Apple, 1985). Yet, while action on the curricula and teaching that dominate our schools may not be sufficient, it is clearly necessary. For it should be clear that the movement toward an authoritarian populism will become even more legitimate if only the values embodied in the conservative restoration are made available in our public institutions. The widespread recognition that there were, are, and can be more equal modes of economic, political, and cultural life can only be accomplished by organized efforts to teach and expand this sense of difference. Clearly, there is educational work to be done. 


\section{Notes}

1. I wish to thank my colleague Walter Secada for this point.

2. Clark and Astuto (1986) point out that during Reagan's terms, the following initiatives have characterized educational policies: reducing the federal role in education, stimulating competition among schools with the aim of "breaking the monopoly of the public school," fostering individual competition so that "excellence" is gained, increasing the reliance on performance standards for students and teachers, an emphasis on the "basics" in content, increasing parental choice "over what, where, and how their children learn," strengthening the teaching of "traditional values" in schools, and expanding the policy of transferring educational authority to the state and local levels (p. 8).

3. I realize that there is debate over the adequacy of this term. Authoritarian populism is, of course, a term that denotes a central tendency of a broad and varied movement, as I show later on in my discussion.

4. For an illuminating picture of how these issues are manipulated by powerful groups see Hunter (1984).

5. I have elsewhere claimed, and point out later, however, that some members of the new middle class-namely efficiency experts, evaluators and testers, and many of those with technical and management expertise-will form part of the alliance with the new right. This is simply because their own jobs and mobility depend on it. See Apple (1986a).

6. The discussion in Bowles and Gintis of the "transportability" of struggles over person rights from, say, politics to the economy is useful here. I have extended and criticized some of their claims in Apple (1988).

7. I say "new" here, but the continuity of, say, African American struggles for freedom and equality also needs to be stressed. See the powerful treatment of the history of such struggles in Harding (1981).

8. For a comprehensive analysis of the logic of capitalism, one that compares it with other political and economic traditions, see Levine (1984).

9. "Substance" in Chicago and "Chalkdust" in New York City are other significant examples of such progressive groups.

\section{References}

Anderson, M. (1985). Teachers' unions and industrial politics. Unpublished doctoral dissertation, Macquarie University, Sydney, Australia.

Apple, M.W. (1985). Education and power (rev. ARK ed.). New York: Routledge.

Apple, M.W. (1986a) Teachers and texts: A political economy of class and gender relations in educations. New York: Routledge \& Kegan Paul. 
Apple, M.W. (1986b). National reports and the construction of inequality. British Journal of Sociology of Education, 7(2), 171-190.

Apple, M.W. (1988). Facing the complexity of power: For a parallelist position in critical educational studies. In M. Cole (Ed.), Rethinking Bowles and Gintis. Philadelphia: Falmer Press.

Apple, M.W. (1990). Ideology and curriculum. (2nd rev. ed.). New York: Routledge.

Bastian, A., Fruchter, N., Gittell, N., Greer, C., \& Haskins, K. (1986). Choosing equality: The case for democratic schooling. Philadelphia: Temple University Press.

Bennett, W.J. (1988). Our children and our country. New York: McGraw-Hill.

Bowles, S. (1982). The post-Keynesian capital labor stalemate. Socialist Review, 12, 51.

Bowles, S., \& Gintis, H. (1986). Democracy and capitalism. New York: Basic Books.

Burnham, W.D. (1983). Post-conservative America. Socialist Review, $13,125$.

Carnoy, M., Shearer, D., \& Rurberger, R. (1984). A new social contract. New York: Harper \& Row.

Clark, D., \& Astuto, T. (1986). The significance and permanence of changes in federal education policy. Educational Researcher, 15, 4-13.

Freedman, S., Jackson, J., \& Boles, K. (1982). The effects of the institutional structure of schools on teachers. Somerville, MA: Boston Women's Teachers' Group.

Gintis, H. (1980). Communication and politics. Socialist Review, 10, 193.

Giroux, H. (1984). Public philosophy and the crisis in education. Harvard Educational Review, 54, 186-194.

Hall, S. (1980). Popular democratic vs. authoritarian populism: Two ways of taking democracy seriously. In A. Hunt (Ed.), Marxism and democracy. London: Lawrence and Wishart.

Hall, S. (1983). The great moving right show. In S. Hall \& M. Jacques (Eds.), The politics of Thatcherism. London: Lawrence and Wishart.

Hall, S. (1985). Authoritarian populism: A reply. New Left Review, $151,122$.

Hall, S. (1986). Popular culture and the state. In T. Bennett, C. Mercer, \& J. Woollacott (Eds.), Popular culture and social relations (pp. 35-36). Milton Keynes, UK: Open University Press.

Hall, S., \& Jacques, M. (1983). Introduction. In S. Hall \& M. Jacques (Eds.), The politics of Thatcherism. London: Lawrence and Wishart.

Harding, V. (1981). There is a river: The black struggle for freedom in the United States. New York: Vintage Books.

Hogan, D. (1982). Education and class formation. In M.W. Apple (Ed.), Cultural and economic reproduction in education (pp. 32-78). Boston: Routledge \& Kegan Paul. 
Hunter, A. (1984). Virtue with a vengeance: The pro-family politics of the new right. Unpublished doctoral dissertation, Brandeis University.

Hunter, A. (1987). The politics of resentment and the construction of middle America. Unpublished manuscript, University of Wisconsin, American Institutions Program, Madison.

Jessop, T., Bennett, K., Bromley, S., \& Ling, T. (1984). Authoritarian populism, two nations and Thatcherism. New Left Review, 147, 33-60.

Larrain, J. (1983). Marxism and ideology. Atlantic Highlands, NJ: Humanities Press.

Levine, A. (1984). Arguing for socialism. Boston, MA: Routledge \& Kegan Paul.

Livingstone D. (Ed.). (1987). Critical pedagogy and cultural power. South Hadley: Bergin \& Garvey.

National Commission on Excellence in Education. (1983, April 27). A nation at risk. Education Week, pp. 12-16.

Omi, M., \& Winant, H. (1986). Racial formation in the United States. New York: Routledge \& Kegan Paul.

Piven, F., \& Cloward, R. (1982). The new class war. New York: Pantheon.

Raskin, M. (1986). The common good. New York: Routledge \& Kegan Paul.

Rose, S. (1988). Keeping them out of the hands of Satan: Evangelical schooling in America. New York: Routledge. 